\title{
The Dynamics of Foreign Public Debt and Foreign Exchange Reserve of Ethiopia: Autoregressive Distributed Lag Model Approach
}

\author{
Solomon Kebede Menza, Zerihun Getachew' Berhanu Kuma, Tora Abebe
}

\begin{abstract}
External public debt and foreign exchange reserve (FER) are performing a crucial role in the growth and development of countries. To examine the short-run and long-run dynamics among external public debt (EPD) and FER in Ethiopia, the study used 39 years data (1981 to 2019) from National bank of Ethiopia (NBE) and World Bank data sets. The Autoregressive Distributed Lag (ARDL) model with error correction model (ECM) was employed after checking the possible assumptions of economic series. The results of ADF test statistics confirms our economic series are stationary with a mixture of level form and first difference form. Bounds co-integration test suggests the existence of co-integration among the variables. According to the descriptive method of data analysis, on average, in Ethiopia the trend for service sector indicated that an ever improvement of the sector throughout the periods and supplementing the notion of change from agriculture base to service sector. On the other hand, according to ARDL model in the short -run on average trade tariff rate, share of manufacturing sector from the GDP, and lagged value of EPD itself predicts the EPD significantly at least at less than $10 \%$ level of significance. Moreover, the ECM revealed that in the long-run, financial development indicator, debt service payment, and average trade tariff rate were predicting the stock of FER for Ethiopian economy. Finally, the concerned body, the government of Ethiopia, should limit or reduce the amount of external debt (ED) inflows, and recheck the budget sources for financing different projects especially manufacturing industries rather than highly basing on external sources in the form of EPD, among others.
\end{abstract}

Keywords: ARDL, Ethiopia, External Public debt, Foreign Exchange Reserve

\section{INTRODUCTION}

In spite of the associated benefits of accumulating FER, most countries of the world are having lower amount of reserves which has led to upheaval among researchers, scholars, commentators, development policy makers and planners on its implication on economic growth.

Manuscript received on August 04, 2021.

Revised Manuscript received on August 11, 2021.

Manuscript published on August 30, 2021.

*Corresponding author

Solomon Kebede Menza*, ( $\mathrm{PhD}$ Candidate),Department of Economics, Wolaita Sodo University, Ethiopia, Email: kebedes24@gmail.com

Zerihun Getachew, (PhD), Principal Advisor, World Bank, Addis Ababa Branch, Ethiopia,

Berhanu Kuma, (PhD) Co-Advisor I, Department of Agricultural Economics, Wolaita Sodo University, Ethiopia,

Tora Abebe, $(\mathrm{PhD})$, Co-Advisor II, Department of Economics, Arba Minch University, Ethiopia.

(C) The Authors. Published by Blue Eyes Intelligence Engineering and Sciences Publication (BEIESP). This is an open access article under the CC BY-NC-ND license (http://creativecommons.org/licenses/by-nc-nd/4.0/)

In particular according to Kurmas A. (2013) for borrowing constrained nations the cost of holding large amount of foreign exchange reserve is higher as compared the benefit of maximizing precautionary savings in the form of hard currency. With respect to Ethiopian economy, data from NBE revealed its erratic patterns and worst one. For instance, the volume of FER was USD 137.584 million in 1981 and declined to USD 81.642 million in 1989. It rose to USD 451.28 million in 1998 and declined to USD 349.153 million in 2001. In 2011, it was USD 3.198 billion but declined to USD 2.972 billion in 2018 (NBE, 2019). These fluctuations with lack of adequate accumulation might have an adverse effect on the growth of Ethiopian economy. Ethiopia has been struggling with a huge shortage of FER for the last two decades. Data for the year 2018 indicated that FER was only adequate to cover 1.6 month of imports. Consequently, many of the businesses waited on average for six months to get foreign currency to import capital goods and services. Moreover, the total reserves as a percentage of total ED was by far lower than developed countries which was $30.56 \%$ for 2010 and 14.23\% for 2018 (World Bank, 2020). From 2000 to 2018, Ethiopia public expenditure increased at exponential rate; majorities were financed by external borrowings that created a huge burden on future generation (World Bank, 2018). The problem of FER accumulation was aggravated by having regularity in huge inflows of public debts. For instance, Ethiopia's debt was equivalent to $60 \%$ of the nation's Gross Domestic Product (GDP) in 2018, which was the highest for the last two decades. This indicated that the nation has been accommodating abnormality in the accumulation of FER and its external public debt capital, which could need a serious of intervention by experts in the arena (World Bank, 2019). Theoretically FER and EPD are two different forces supplementing each other because a large accumulation of ED calls massive debt servicing obligations by creditors which by itself affects FER dramatically in the long run, affecting the needs of future generation adversely. This shows external obligations are financed from the stock of foreign reserves of the host nation. This in turn influences exchange rate of the local currency, in our case Ethiopia Birr. Hence, it is underlined that FER stock is a major indicator for debtor nation's ability and capacity to service on the ED (Onwuka and Igwezea, 2014). On the other hand, debt repayment problem is a serious issue for a country having an export earnings of approximately USD 2.64 billion per month for the period in between 2000 to 2018, as compared to USD 0.25 billion of debt to pay back per month (NBE, 2018 and MoFED, 2018). Literatures indicated scanty studies in relation to the two macroeconomic variables emphasizing Ethiopian economy.

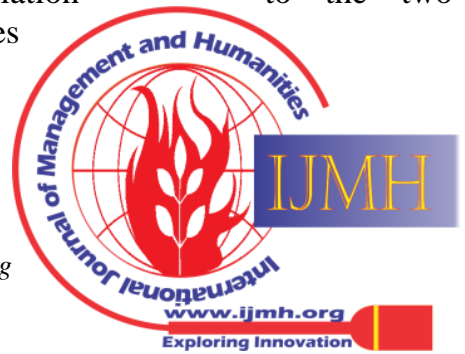




\section{The Dynamics of Foreign Public Debt and Foreign Exchange Reserve of Ethiopia: Autoregressive Distributed Lag Model Approach}

An investigation for five countries in Asia and Latin America adopting Markov switching approach of modelling found that public debt had increased the probability for a country to suffer from financial crisis; however FER did not necessarily provide "Peace" for indebted nations having some exceptions. He concluded that although public debt and FER have an opposite association in economic theories for a nation, the negative effects of public debts is greater than the beneficial effects of FER (Layal, 2013). Others like Senibi et al. (2016) investigated the impact of public debt on FERs in Nigeria using a data covering time span of 1981 to 2013 and found that public debt had a positive and statistically significant impact on FER. In contrary, Peter and Dumani (2020) for the period 1981 to 2018 using ECM of analysis found that ED stock exerted a negative and statistically significant impact on Nigeria's FER portfolios.

According to Layal (2013) investigating the relationship between FER and EDs in indebted countries from Asia and Latin America showed the harmful effects of EDs exceed in most cases the beneficial effects of FER. Studies in Bangladesh examining the relationship among ED, FER and economic growth, concluded that there existed a unidirectional causation from ED to FER as of the Granger-causality results (Shariful et al., 2018). Other scholars in examining the impact of public debt on FER of Hungarian economy found that although debt in the form of hard currency can contribute to the growth of FER, it can drive serious difficulties in assessing the adequacy of reserve. They further indicated the issue aggravates during a crisis when it becomes almost unachievable to refinance maturing public debts at a time when the reserve requirement may be still increasing. Thus, the study concluded that rising public debt causes uncertainty in FER dynamics (Gergely et al., NA).

Alfaro and Kanczuk (2005) on the other hand stressed that both FER and ED were not perfect substitutes yet both were denominated in foreign currency. Subsequently their study pinpointed that FER stock did not play a quantitatively critical role by means of even consumption and hence FER accumulation did not raise debt sustainability. Victoria et al. (2016) in Nigeria using Fully Modified Ordinary Least Square found that debt had a positive and statistically significant effect on FER accumulation in the long run that suggests the country's debt crisis is the result of both exogenous and endogenous constituents such as economic policies, the nature of the economy, higher dependence on oil, and swindling FER. However, the study by Peter and Dumani (2020) for the period covering 1981 to 2018 of Nigerian economy empirically found that ED stock had a negative and statistically significant impact on FER accumulation of the nation. The above empirical studies were limited on considering aggregate public debt's value and hence the current research is justified on the grounds that it has focused by disaggregating EPD into major types of debts and only considers the long-term 1 EPD flows in Ethiopian economy. This is due to the fact in Ethiopia long-term foreign public debt takes the lion share from the total debt

\footnotetext{
1 Long term external public debt is debt that has an original or extended maturity of more than one year. It has public, publicly guaranteed and private non-guaranteed debt components.
}

inflows across the time span from 1970 to 2019. Furthermore, using the trimmings methods of decomposition developed by Meyer (1999), the consideration of decomposing of EPD yields that the long-term ED is relatively the one having the permanent (trend) component and all the rest are showing a cyclical movement for the time periods. Last not least, the issue of dynamics among EPD and FER are a clear cut in need of study considering Ethiopian economy with the absence of studies relating the two macroeconomic variables feeding one another. Thus, this study examined the short-run the period 1981-2019.

\section{THEORETICAL LITERATURE REVIEW}

\section{$>\quad$ Theory of FER and Public Debt}

According to Fukuda and Kon (2010) governments have different financial interventions to accommodate an increase in FERs. Here we can assume that the Ricardian equivalence holds, thus any ways of financing does not affect resource allocations at steady-state level. Further we assume that the return from FER is very small in the international financial market. A sudden (unanticipated) large increase in reserve cumulation calls an ED to finance the imbalances at - state level. In other hand, an increase in ED needs a which implies that large accumulation of reserve is financed by lump-sum taxes. Others also supplements that unexpected accumulation of reserve increases the share of uid ED from the total ED. This is because of the fact that term debts are more liquid than long term debts as

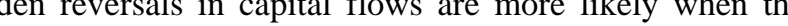
increase in shifts the accusation of debt from long term to short term debt. Hence, FER has a positive effect on the total ED and a negative effect on maturity periods. However, in situation of nations having relatively large trade openness the share of foreign currency like US dollar takes the lions share from the total FER (HiroIto and Robert , 2019)

\section{The dual gap theory of external debt and self-insurance theory of reserves}

The aspiration of every nation is to achieve greater economic growth rate especially the developing nations. But growth requires investment on goods and services, which may either be produced in home in the form of public savings or be purchased from abroad in the form of borrowings, Foreign Direct Investment (FDI), loans, donations. But domestic investment is not strained by prior saving but in the end saving must match planned investment for real capital accumulation to take place. While the growth source from abroad requires the flow of foreign exchange, it is also true to a large extent that a certain type of capital goods can only be procured from abroad or can be invited in the form of FDI.

Traditionally, the role of foreign capital has been seen as supplement to domestic investment to bridge an investment-saving gap and achieve growth. 
Therefore, a minimum amount of foreign exchange is always needed to sustain the growth endeavor.

Yet in the case of FDI, developing countries prefers FDI form of investment than importing capital goods from abroad, as they usually face the shortage of foreign exchange. In fact in the real world developing nations are expanding growth sources from abroad in different interventions including FDI. However, the thought of dual-gap theory, which was introduced by Hollis Chenery and others shows that foreign borrowings may also be viewed as a supplement to FER if to attain a quicker rate of growth and development, the gap among foreign exchange earnings from exports and necessary import expenses is larger than domestic investment-saving gaps, and home and external resources are not easily substitutable for one another. External capital must fill larger of the two gaps if target growth rate is to be attained. This process through which this can be explained is known as Dual-gap theory.

Other theory that supplements dual gap theory is self-insurance theory of reserves which estate putting aside funds in order to decrease possible unfortunate fortune. It simply means maintaining a minimum adequate stock to intervene on external shocks. Thus, the self-insurance theory of foreign reserves holds that nations should accumulate international reserves in the form of hard foreign currency, bank deposits, near money instruments in foreign denominations that would help in the time of short falls of domestic economy. The theory proposes that this would help the country to decrease foreign shocks and serve as a minimum block of stock to intervene on the foreign exchange rate of a country. Thus, the theory holds that reserve accumulation assure the refund ability and capacity of the nation, as well as the remedy to mitigate the shortfalls of domestic gaps existing in trade balance (Akamobi and Ugwunna, 2017).

\section{> Debt Overhang Effect of external debt}

Debt overhang effect is measured by the percentage share of total public debt from GDP as an indicator of debt burden. According to Krugman (1988), a nation's debt is said to be over-hanged when a accumulation of foreign debt exceeds a nation's capacity to repay and resulted in debt liability. This higher debt repayment service obligation forces a government to levy higher taxes on private sector to supplement shortage of repayment capacity as per contractual agreement with creditors. Higher taxes discourage incentive to save and invest in productive activities. Consequently, resources that might have funded for investments are shifted to cover debt (Claessens et al., 1990 and Sachs, 2002). This shows that as the foreign debt grows large, the expected return from investment becomes lower, which discourages private investment and slows capital stock accumulation. Thus, debt overhang acts as a tax imposed on future income which discourages both domestic and foreign investment, decreases the rate of economic growth and acts as a constraint for highly indebted countries escaping from extreme poverty (Bangura, 2004; Clements et al., 2003). Others describe the transition mechanism of foreign public debt on investment via debt overhang scenario and credit rationing scenario. In the same manner they call the situation where debtor country gain a few from the marginal return of investment due to the debt service obligations as debt overhang. If an increase in debt overhang is not accompanied with an increase in domestic savings, the sources for foreign saving will dry-up and thereby interest rate on domestic loan rises above the international rate. This shows that the debtor country do not have any access to obtain additional loans because of the country failed to service the existing debts from foreign nations. This situation is termed as credit rationing by foreigners (Borensztein, 1990).

\section{Crowding out effect of external debt}

Crowding out effect is measured by the ratio of debt service to exports of goods and non-factor services as an indicator of debt burden. The higher the ratio, the higher will be crowding out effect of ED. A liquidity constraint refers to the inability of a country to finance its debts now in the amount contracted at the beginning due to lack of enough cash on hand to repay current obligations. Solvency refers to either the value of a country's liabilities exceeds the ability to pay or not at any time; it also indicates signs for incapability of a country servicing its debt in the long run. If a country's debt-GDP ratio and the debt-service ratio are high, the country will be illiquid and its ability to remain solvent will also be diminished. Therefore, the county needs to follow accelerated growth in order to reduce its debt problems (Ajayi, 1991). Liquidity constraint represents a crowding effect of ED, arises from the increase in debt repayment may shift the budget away from the public investment to cover debt obligation. They underlined that government expenditure is a major determinant of the economic activities in many functional sectors. They also argued that debt can additionally contribute to economic growth through its effect on the productivity of investment and decrease output growth by reducing productivity and as a result of the unfavorable changes in investment mix. Hence, crowding out effect reduces capital formation and encouraging capital flight because of an increase in expected level of taxation (Cohen, 1993; Fosu, 1996; Taylor, 1994). In other hand, according to Claessens (1990) the resources utilized to service debt may crowd-out public sector investment and hence discourage private investment, due to the complementarity of private and public investment. As debt servicing needs higher domestic resources, so the share of public investment will fall as most governments cannot reduce public consumption. When there is less public expenditure on basic infrastructure, private investment will also be discouraged. The strong demand of high debt service payments on the budget results in forced reduction in public investment including investment in human capital (education and health) as well as it discourages private investment. This shows that lack of debt servicing capacity of the country discourages aggregate investment thereby reduces output and economic growth. We call this transition of ED on economic growth as the crowding-out effect of debt.

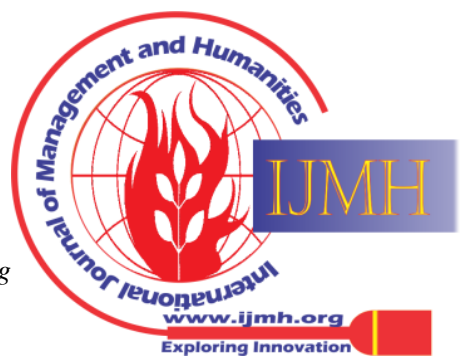




\section{The Dynamics of Foreign Public Debt and Foreign Exchange Reserve of Ethiopia: Autoregressive Distributed Lag Model Approach}

\section{METHODOLOGY}

\section{$>\quad$ Data Type and Sources}

This study used secondary data from NBE and World Bank data sets. The main macroeconomic variables under this study were FER, EPDt (the long-term external public debt), Financial development indicator (Is the level of financial development measured by the ratio of money supply to GDP), Debt service payments (DSP), Trade openness (Is the average tariff rate as a proxy for trade openness) and the share of economic sectors from GDP (Is the proxy for structural transformation and measured by the value added by each major economic sectors; primary, manufacturing and service sector) which were stated in the model specification part of the article as a control variables over the period covering from 1981 to 2019 as of annual data, with a total of 39 years that adequately displays the reliability and validity of the time variants.

\section{$>\quad$ Method of Data Analysis}

This study used both descriptive and econometrics analysis methods. Descriptive analysis used tables, figures, charts, historical trends; mean, standard deviation, maximum and minimum values for targeted variables as well as other countries included in the panel. Econometrics analysis adopted ARDL and ECM.

\section{$>\quad$ Empirical Model for Dynamics of EPD and FER}

The theoretical framework of dynamics among EPD and FER is based on the theory of optimal reserves allocation that the government faces as a problem that is not solved by domestic sources of income. Thus, this model shows the decision of borrowing from foreigners is inevitable with the existing situations of the domestic economy to curb the imbalances. Later on, this model extended to a dynamic model to provide a theory for the increment in FER and the form of sudden stops in economies of emerging countries. It states that while temporary reserves, temporary liquidation and the interest rate are part of the aggregate liquidity shock, the rollover policy is a part of both aggregate state and individual liquidity daze of an investor. In these times EPD contractual agreement is resource feasible on the hands of the government. On other hand, start-up FER and invested capital cannot be above the loan amount; and similarly, temporary reserves and temporary payments cannot be above the initial FER and temporary output of the nation. Obviously, the main conflict here is that the government cannot lend the current against the future output from the initial investment. Hence, liquidation and reserves are the only sources to make current debt payments. Similarly, final output and remaining reserves are the only sources available to make payments at final stages. The model recommends a precondition which requires that the current rollover policy is to change the loan if and only if rolling over provides a better payment than calling the loan in the interim. To examine the dynamics among EPD and FER, this study takes evidence from the theory of optimal foreign reserves allocation in analyzing this dynamics; the first one is FER usually denominated in hard currency in the form of foreign currencies. The second one is borrowing by state from foreign source is inevitable in times of internal economic crisis, this in turn is a sign of a fall on the future reserve stock. Moreover, economic theory suggests that an increase in FERs not only raises ED but also drives a shift from illiquid to liquid public debt. Accordingly, the functional relationship is specified as:

$$
E P D_{t}=f\left(F E R_{t}, F D_{2 t}, D S P_{t}, T_{t}, S S_{i t}\right) \ldots \ldots \ldots \ldots(1)
$$

where FERt stand for FER at period t, EPDt stand for EPD taking long-term external public debt as permanent component of debt at period t, FD stands for the level of financial development index as measured by money supplied, M2, over GDP, DSPt stands for debt service payments at period $\mathrm{t}$, Tt stand for trade openness taking average trade tariff rate at period t as a proxy and SSit stands for the ith major economic sector's share from the GDP at period t.

Transforming equation (1) into mathematical equation by applying logarithmic relations, we have the following:

$\ln (E P D)_{t}=\beta_{0}+\beta_{1} \ln (F E R)_{t}+\beta_{2} \ln (F D)_{t}+$ $\beta_{3} \ln (D S P)_{t}+\beta_{4}(T)_{t}+\beta_{5 i} \ln (G D P)_{i t}+\varepsilon_{i t} \ldots$ (2)

To examine the dynamic effects of FER, EPD on sectoral economic growth, we augment a standard growth specifications based on conditional convergence by adding GDPit variables where i stands for the three economic sectors (agriculture, manufacturing and service sector) and others like openness as a control variables (See Mankiw et al., 1992; Bajo-Rubio 2000). Hence, our empirical approach departs from this approach and explores the dynamics using an aggregate output function augmented by adding other control variables to mitigate the inflated associations among EPD FER and their respective effect on sector wise economic growth. Equation (4) can be estimated using sufficiently long time series and applying co-integration econometric methods. If the time variants fulfills the basic assumptions of econometrics models we may adopt the ARDL bounds test approach to co-integration proposed by Pesaran and Shin (1999) and Pesaran, Shin and Smith (2001). This approach is relatively better than the commonly used approaches, the le equation procedure formulated by Engle and Granger (1987) and the maximum likelihood method (MLM) postulated by Johansen (1991, 1995), by providing the ollowing three basic advantages: variables to be integrated of order 1, this necessarily integration of the macroeconomic series, which may lead to some uncertainty in the analysis of long-run relations. In comparison, ARDL approach allows the analysis of long-term relationships between variables, regardless of whether they are integrated of order 0 (I(0)), of order 1 (I(1)) which avoids some of the common pitfalls faced in the empirical analysis of time series, such as the lack of power of unit root tests and doubts about the order of integration of the variables (Pesaran et al., 2001).$$
\text { seserved. }
$$

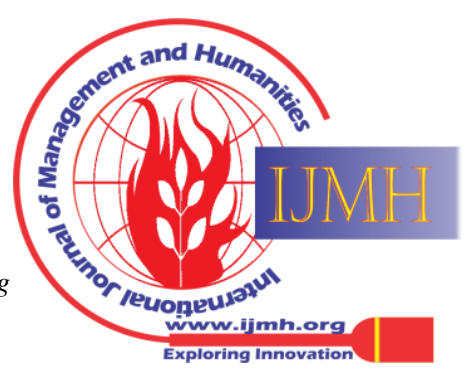


$\checkmark \quad$ Second, the ARDL approach allows a distinction to be made across the dependent variable and the independent variables, an obvious advantage over the method proposed by Engle and Granger; as of the Johansen approach, it provides simultaneous estimation of the short-run and long-run parts, eliminating the problems related to omitted variables and the existence of auto-correlation.

$\checkmark \quad$ Third, while the estimation results obtained by the techniques pinpointed by Engle and Granger and Johansen are not robust to small samples, Pesaran and Shin (1999) show that the short-run parameters estimated using their techniques are consistent and that the long-run parameters are super-consistent in small samples.
Accordingly, the econometrics model is specified as:

$$
\begin{gathered}
\operatorname{sln} E P D_{t}(p, q)=\mu_{0 i}+\sum_{i=1}^{p} \delta_{i} \ln E P D_{t-i}+ \\
\sum_{i=0}^{q} \beta^{\prime} X_{t i}+\varepsilon_{i t} \ldots \text { (3) }
\end{gathered}
$$

Where $\operatorname{lnEPD}$ is the outcome variable, $\beta$ and $\mathrm{X}$ are vectors for the parameter term and explanatory variables, $\mu$ oi is the intercept term, $\delta \mathrm{i}$ is the coefficient for the lagged value of EPD, $p$ and $q$ are the optimal lag length for the dependent variable, EPD, and explanatory variables.

Simplifying equation (3) to include the variables of interest in the study, we have:

$$
\begin{aligned}
& \ln E P D_{t}=\beta_{0 i}+\sum_{i=1}^{p} \delta_{i} \ln E P D_{t-i}+\sum_{i=1}^{q_{1}} \beta_{1} \ln F E R_{t-i}+\sum_{i=1}^{q_{2}} \beta_{2} \ln F D_{t-i}+\sum_{i=1}^{q_{3}} \beta_{3} \ln D S P_{t-i}+\sum_{i=1}^{q_{4}} \beta_{4} T_{t-i}+. \\
& \sum_{i=1}^{q_{5}} \beta_{5} \ln \mathrm{Agr}_{t-i}+\sum_{i=1}^{q_{6}} \beta_{6} \ln \operatorname{Man}_{t-i}+\sum_{i=1}^{q_{7}} \beta_{7} \ln S v s_{t-i}+\varepsilon_{i t} \ldots . \text { (4) }
\end{aligned}
$$

The first step in the ARDL model is to perform the Bounds test for co-integration to check the existence of long-run relationship between variables. If the variables with $\mathrm{I}(0)$ and $\mathrm{I}(1)$ the use of Johansen co-integration test is no longer valid, hence the appropriate test is the Bounds test proposed by Peseran et al. (2001). Thus, the Bounds test hypothesis is written as:

$$
\begin{aligned}
& H_{0}: \beta_{1 i}=\beta_{2 i}=\beta_{3 i}=\beta_{4 i}=\beta_{5 i}=\beta_{6 i}=\beta_{7 i}=0 \\
& H_{1}: \beta_{1 i} \neq \beta_{2 i} \neq \beta_{3 i} \neq \beta_{4 i} \neq \beta_{5 i} \neq \beta_{6 i} \neq \beta_{7 i} \neq 0
\end{aligned}
$$

Since our variable of interest are eight we can have eight co-integration tests, which are applied on the following equations:

$$
\begin{aligned}
& \underset{\mathrm{p}}{\ln E P D_{\mathrm{t}}}=\mathrm{a}_{01}+\beta_{1 \mathrm{~d}_{1}} \ln _{1} \mathrm{PD}_{\mathrm{t}-\mathrm{i}}+\beta_{21} \operatorname{lnFER}_{2} \mathrm{E}_{\mathrm{t}-\mathrm{i}}+\beta_{31} \mathrm{FD}_{\mathrm{t}-\mathrm{i}}+\beta_{411} \operatorname{lnDSP}_{\mathrm{t}-\mathrm{i}}+\beta_{51} \mathrm{~T}_{\mathrm{t}-\mathrm{i}}+\beta_{61} \ln _{\mathrm{Agr}} \mathrm{tg}_{\mathrm{t}-1}+\beta_{71} \mathrm{Man}_{\mathrm{t}-1}+\beta_{81} \mathrm{Svs}_{\mathrm{t}-\mathrm{i}}+ \\
& \sum_{\mathrm{i}=1}^{\mathrm{p}} \mathrm{a}_{1 \mathrm{i}} \Delta \operatorname{lnEPD} \mathrm{L}_{\mathrm{t}-\mathrm{i}}+\sum_{\mathrm{i}=1}^{1} \mathrm{a}_{2 \mathrm{i}} \Delta \ln F E R_{\mathrm{t}-1}+\sum_{\mathrm{i}=1}^{2} \mathrm{a}_{3 \mathrm{i}} \Delta \mathrm{FD}_{\mathrm{t}-\mathrm{i}}+\ldots+\sum_{\mathrm{i}=1} \mathrm{a}_{8 \mathrm{i}} \ln _{\ln S v \mathrm{~s}_{\mathrm{t}-\mathrm{i}}}+\mathrm{e}_{\mathrm{it}} \ldots . .(5)
\end{aligned}
$$

$\Delta \ln F E R_{t}=a_{\mathrm{p} 2}+\beta_{12} \ln E P D_{t-i}+\beta_{22} \ln F E R_{t-i}+\beta_{32} F_{q_{2}} D_{t-i}+\beta_{42} \ln D S P_{t+i_{i 1}}+\beta_{52} T_{t-i}+\beta_{62} \ln A g r_{t-1}+\beta_{72} M a_{t-1}$ $+\beta_{82} S v S_{t-i}+\sum_{i=1}^{\rho} a_{1 i} \Delta \ln F E R_{t-i}+\sum_{i=1} a_{2 i} \Delta \ln E P D_{t-1}+\sum_{i=1} a_{3 i} \Delta F D_{t-1}+\ldots+\sum_{i=1}^{t i t} a_{8 i} \Delta \ln S v s_{t-1}+e_{i t} \ldots$

$\Delta \ln S v s_{t}=a_{0 \otimes p}+\beta_{18} \ln E P D_{t-i}+{ }_{q} \beta_{28} \ln F E R_{t-i}+\beta_{38} F_{q_{2}} D_{t-i}+\beta_{48} \ln D S P_{t-i} q_{71}^{+} \beta_{58} T_{t-i}+\beta_{68} \ln$ Agr $_{t-1}+\beta_{78} M \operatorname{Man}_{t-1}$ If $+\beta_{88} S v s_{t-i}+\sum_{i=1} a_{1 i} \Delta \ln S v s_{t-i}+\sum_{i=1} a_{2 i} \Delta \ln E P D_{t-1}+\sum_{i=1} a_{3 i} \Delta F E R_{t-i}+\ldots+\sum_{i=1} a_{8 i} \Delta \ln S v s_{t-i}+e_{i t} \ldots$

there is no-co-integration, the ARDL model is specified as

$\Delta \ln E P D_{t}=a_{01}+\beta_{11} \ln E P D_{t-i}+_{q} \beta_{21} \ln F E R_{t-i}+\beta_{31} F_{q_{2}} D_{t-i}+\beta_{41} \ln D S P_{t-\dot{q}_{7}}+\beta_{51} T_{t-i}+\beta_{61} \ln A g r_{t-1}+\beta_{71} M{ }^{2} n_{t-1}$ $+\beta_{81} S_{v s_{t-i}}+\sum_{i=1}^{a_{1 i}} a_{1 i} \Delta \ln E P D_{t-i}+\sum_{i=1}^{1} a_{2 i} \Delta \ln F E R_{t-1}+\sum_{i=1}^{q_{2}} a_{3 i} \Delta F D_{t-i}+\ldots+\sum_{i=1} a_{8 i} \Delta \ln S v s_{t-i}+e_{t} \ldots . .(8)$

This could be applied for other variables as an outcome variable depending on the objective of the researchers. But if we reject the null hypothesis of no-co-integration, we have the following error correction model (ECM) specified as:

$\Delta \ln E P D_{t}=a_{01}+\beta_{1 i} \ln \underset{p}{E} P D_{t-i}+\beta_{2 i} \ln F E R_{t_{i-i}}+\beta_{3 i} F D_{t-i}+\beta_{4 i} \ln _{t_{2}} D S P_{t-i}+\beta_{5 i} T_{t-i}+\beta_{6 i} \ln A g r_{t-1}+$ $\beta_{7 i} \operatorname{Man}_{t-1}+\beta_{8 i} S v s_{t-i}+\sum_{i=1}^{p} a_{1 i} \Delta \ln E P D_{t-i}+\sum_{i=1}^{t_{1}-i} a_{2 i} \Delta \ln F E R_{t-1}+\sum_{i=1} a_{3 i} \Delta F D_{t-i}+\ldots$

$+\sum_{i=1}^{q_{7}} a_{8 i} \Delta \ln S v s_{t-i}+\lambda E C T_{t-1}+e_{t}$

the speed of adjustment (error correction term);

a1i, a21, ., a8i are the short-run dynamic coefficient; $E C T=\left(\ln E P D_{t-i}-\theta X_{t}\right) ; \mathrm{X}$ is a vector of explanatory variables;

$\theta=\frac{\sum_{i=1}^{q} \beta_{i}}{a_{01}}$ which is the long-run dynamic coefficient.

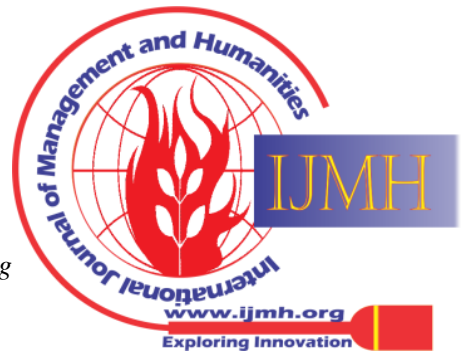




\section{The Dynamics of Foreign Public Debt and Foreign Exchange Reserve of Ethiopia: Autoregressive Distributed Lag Model Approach}

\section{RESULTS}

According to data set presented in Table 1, the mean values of EPD, FER, DSP, share of agricultural, share of manufacturing, and share of service sector from GDP, financial development indicator and trade tariff rate for Ethiopian economy were USD 9.163 billion, USD 1.21 billion, USD 6.15 billion, 45.92\%, 4.75\%, and 36.06\%, 0.0033 and 17.14, respectively. Whereas the minimum (maximum) values of EPD, FER, DSP, share of agricultural,

\section{$>$ Descriptive Analysis Results}

share of manufacturing, and share of service sector from GDP, financial development indicator and trade tariff rate for the Ethiopian economy are USD 1.64 Billion (USD 27.5 Billion), USD 55.2 Million (USD 3.99 Billion), USD 143.4 Million (USD 58.1 Billion), 31.11 (63.83), 3.11 (7.30), and 26.83 (42.75), $0.0004 \quad(0.011)$ and 9.931728 (35.18), respectively.

Table 1: Summary Statistics of variable in the study

\begin{tabular}{|c|c|c|c|c|}
\hline Variable & Mean (N=39) & Std. Dev. & Min & Max \\
\hline External Public Debt (in \$) & 9.16 Billion & 6.62 Billion & 1.64 Billion & 27.5 Billion \\
\hline Foreign Exchange Reserve (in \$) & 1.21 billion & 1.18 Billion & 55.2 Million & 3.99 Billion \\
\hline Debt servicing (in \$) & 6.15 Billion & 12.5 Billion & 143.4 Million & 58.1 Billion \\
\hline Share of Agriculture (in \%) & 45.92 & 7.76 & 31.11 & 63.83 \\
\hline Share of manufacturing (in \%) & 4.75 & 0.90 & 3.11 & 7.30 \\
\hline Share of service (in \%) & 36.06 & 4.06 & 26.83 & 42.75 \\
\hline Financial Development Indicator & .0033442 & .0028659 & .0003609 & .0107967 \\
\hline Trade Tariff Rate & 17.14117 & 7.504662 & 9.931728 & 35.18 \\
\hline
\end{tabular}

Source: By author using STATA 13, 2021.

In Figure 1, EPD and FER trends showed a little bit irregularity which was pinpointing how the economy has fluctuated. The rate of increment was high around 2014 showing a shift of 1.6 billion from US Dollar 1.2 billion for EPD and from US Dollar 2.4 billion to US Dollar 3.5 billion for FER. This fact might
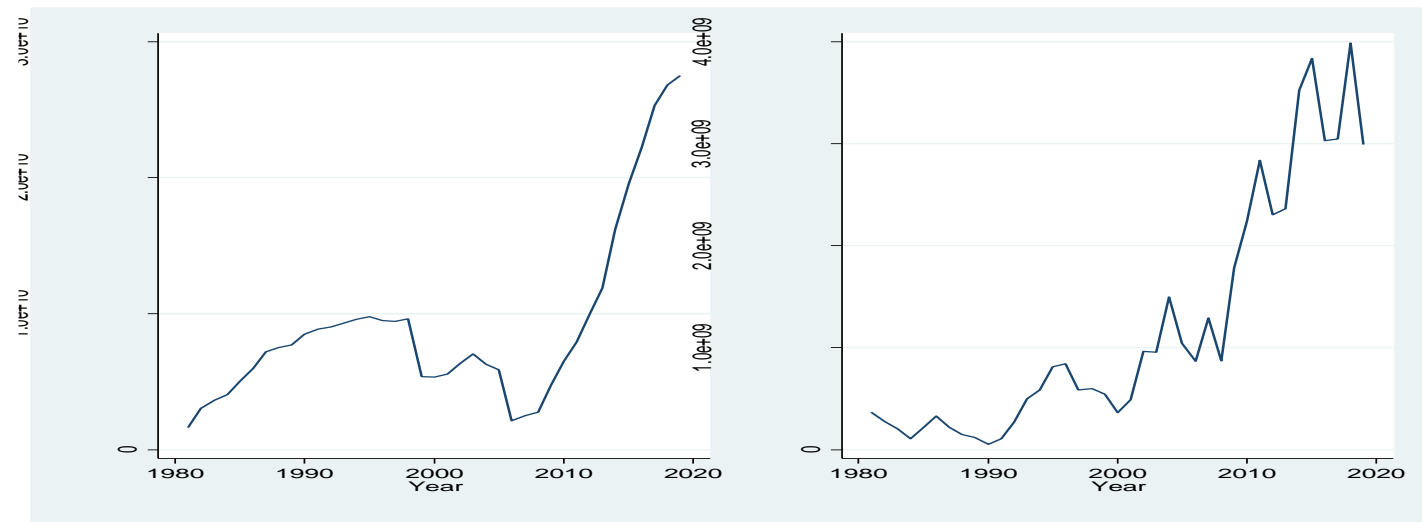

Figure 1: External public debt and foreign exchange reserve trend in Ethiopia

Source: By author using STATA 13, 2021

be related with the highest level of economic growth in 2014, which is around 13.6\% (UNDP, 2020). Later on the EPD of Ethiopia increased dramatically as of the government investment on industrial parks and different Mega projects like Grand Ethiopian Renaissance Dam (GERD). FER of Ethiopia showed a little bit cyclical trend while taking the worst ever in the year 1990s, at a time when there was transitional movement to over-through the previous government, Dergue (the military regime). The FER level in Ethiopia showed an improvement after the downfall of the Dergue in 1991 and yet limited with the

maximum amount below USD 4 billion. On other hand, the EPD showed an upward incremental movement except for the period between 1998 and 2011. The EPD was trending geometrically especially after 2012 and reached the pick of USD 27.5 billion in 2019. These all show that the economy of Ethiopia had transferred burdens to next generation with high ED and shortage of reserves.

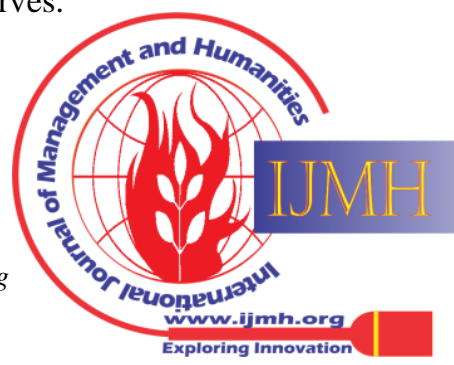


In Figure 2, the trend statistics showed the share of economic sectors in GDP from 1981 to 2019. Accordingly, the share of agriculture in the national GDP has declined from the year 1992 onwards due to structural changes that took place to accommodate the structural adjustment program of 1992/93. While the manufacturing sector had a cyclical trend yet indicating a major improvement after 2010 due to the adoption of growth and transformation plan (GTP) I and II with the objective of transforming the economy from traditional agriculture dominance to manufacturing sector in the last 10 years, 2010-2020. However, on average, the trend for service sector depicted an ever improvement of throughout the periods and supplementing the notion of change from agriculture base to service sector. This might be due to the fact that on the last decades the expansion of service sector like hotel, tourism, lodge, and etc. have taken the lions share.
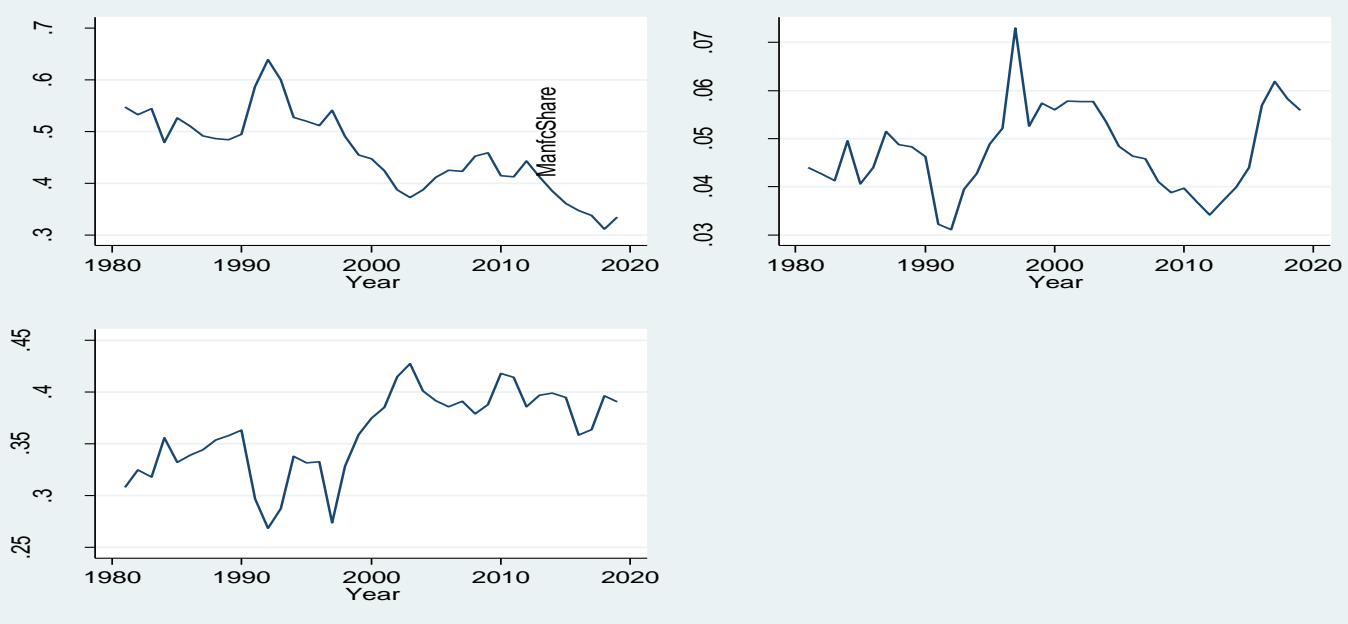

Figure 2: Share of major economic sectors of GDP, Ethiopia.

Source: By author using STATA 13, 2021

\section{Econometrics Results}

According to Dickey Fuller (DF) test result all variables were not-stationary at level form except trade tariff rate, which are stationary at level form. In other words, variables such as EPD, FER, financial development indicator, DSP, share of major economic sectors from GDP were not stationary at level form. Thus, by taking the first difference for non-stationary variables and applying the DF test on their respective first difference the series become stationary. In general the existence of stationarity of variables at both I (0) and I (1) forces us to adopt the ARDL model for the analysis purpose by checking the existence of co-integration between variables (Table 2).

Table 3: Dickey Fuller test for unit root

\begin{tabular}{|c|c|c|c|c|c|c|}
\hline \multirow{3}{*}{ Variables } & \multirow{3}{*}{$\begin{array}{c}\text { MacKinnon } \\
\text { Approximate } \\
\text { p-value }\end{array}$} & \multicolumn{4}{|c|}{ Dickey Fuller (DF) Test statistics } & \multirow[b]{3}{*}{ P-Values } \\
\hline & & \multicolumn{2}{|c|}{ Level } & \multicolumn{2}{|c|}{ First Difference } & \\
\hline & & $\begin{array}{l}\text { Test } \\
\text { Statistics }\end{array}$ & $\begin{array}{l}\text { Critical } \\
\text { value at } \\
5 \%\end{array}$ & $\begin{array}{l}\text { Test } \\
\text { statistics }\end{array}$ & $\begin{array}{l}\text { Critical } \\
\text { value at } \\
5 \%\end{array}$ & \\
\hline EPD & 0.5172 & -1.533 & -2.964 & -5.077 & -2.966 & $0.0000 * *$ \\
\hline FER & 0.8141 & -0.817 & -2.964 & -5.367 & -2.966 & $0.000 * * *$ \\
\hline $\begin{array}{l}\text { Financial } \\
\text { development } \\
\text { indicator }\end{array}$ & 1 & 2.768 & -2.964 & -4.033 & -2.966 & $0.0012 * * *$ \\
\hline Debt servicing & 0.9496 & -0.098 & -2.964 & -5.294 & -2.966 & $0.0000 * * *$ \\
\hline $\begin{array}{l}\text { 1/ijmh.L13710851221 } \\
\text { 371.0851221 } \\
\text { jmh.org }\end{array}$ & & & $\begin{array}{r}\text { Publisl } \\
\text { Blue E } \\
\text { \& Scie } \\
19 \text { (C) Cop }\end{array}$ & $\begin{array}{l}\text { d By: } \\
\text { s Intellige } \\
\text { es Publica } \\
\text { ight: All ri }\end{array}$ & $\begin{array}{l}\text { Engineering } \\
\text { ts reserved. }\end{array}$ & \\
\hline
\end{tabular}


The Dynamics of Foreign Public Debt and Foreign Exchange Reserve of Ethiopia: Autoregressive Distributed Lag Model Approach

\begin{tabular}{lcccccc} 
Trade tariff rate & $0.0060^{*}$ & -3.586 & -2.964 & - & - & - \\
$\begin{array}{l}\text { GDP of } \\
\text { Agriculture }\end{array}$ & 0.7345 & -1.05 & -2.964 & -5.206 & -2.966 & $0.000^{* * *}$ \\
$\begin{array}{l}\text { GDP of } \\
\text { Manufacturing }\end{array}$ & 0.1454 & -2.387 & -2.964 & -7.031 & -2.966 & $0.0000^{* * *}$ \\
$\begin{array}{l}\text { GDP of Service } \\
\text { Total labor }\end{array}$ & 0.2131 & -2.181 & -2.964 & -6.053 & -2.966 & $0.0000^{* * *}$ \\
force & 1 & 35.971 & -2.964 & - & - & - \\
\hline
\end{tabular}

Note: ${ }^{* *},{ }^{* *}$ and $*$ indicates less than $1 \%, 5 \%$ and $10 \%$ significance level, respectively.

Source: By author using Stata 13, 2021

To determine optimum lag length of economic series we used the LL, LR, FPE, SBIC, AIC and HQIC statistical outputs. Accordingly, FPE test result recommends optimum lag length as 4 years and SBIC test result recommends lag length as 1 year. While LR, AIC and HQIC suggest that the appropriate lag length is 3 years. Thus, the appropriate lag length that was selected in the analysis was three years as of majority of the criteria recommends it (Table 3).

Table 4: Lag Length Selection-order Criteria

\begin{tabular}{cclllll}
\hline Lag & LL & LR & FPE & AIC & HQIC & SBIC \\
\hline 0 & 385.215 & & $6.0 \mathrm{e}-20$ & -21.5551 & -21.4324 & -21.1996 \\
1 & 624.741 & 479.05 & $2.9 \mathrm{e}-24$ & -31.5852 & -30.4807 & $-28.3856^{*}$ \\
2 & 713.484 & 177.49 & $1.3 \mathrm{e}-24$ & -32.9991 & -30.9128 & -26.9554 \\
3 & 842.696 & $258.42^{*}$ & $2.8 \mathrm{e}-25$ & $-36.7255^{*}$ & $-33.6575^{*}$ & -27.8378 \\
4 &. &. & $.-9 . e-116^{*}$ &. &. &. \\
\hline
\end{tabular}

Note: * lag order selected by the criterion, Source: By author using Stata 13, 2021

To identify the existence of co-integration among economic series ARDL Bounds tests was used. According to Peseran et al. (2001) if calculated F-statistics is greater than F-critical value of upper bound I(1), we reject the null hypothesis of co-integration and conclude that there is co-integration, long-run relationship between the economic series. While if calculated F-statistics is less than F-critical value of lower bound $\mathrm{I}(0)$, we fail to reject the null hypothesis and conclude that there is no-co-integration among the variables. In addition, if calculated F-statistics is in between F-critical value of lower bound I(0) and upper bound I(1), we conclude that the test result is inconclusive and simply we can estimate the ARDL model to examine the short-run dynamic relationship among variables. In case-1 assuming EPD as dependent variable calculated F-statistic is 1.507, which is below the lower bounds (2.32) at less than $5 \%$ significance level, thus we accept Ho and conclude that there is no co-integration among variables (Table 4). Hence we can estimate ARDL model for short-run dynamics.

Table 5: Pesaran/Shin/Smith (2001) ARDL Bounds Tests for Co-integration

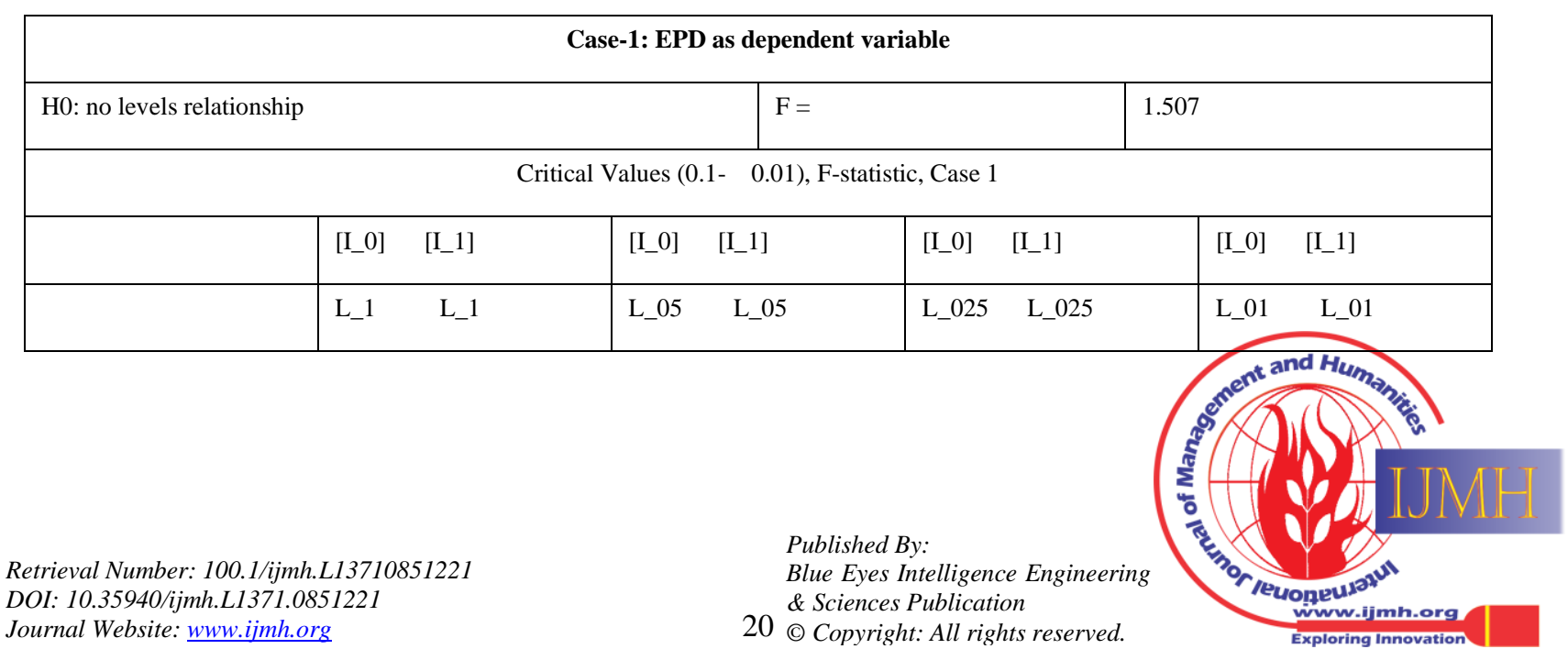




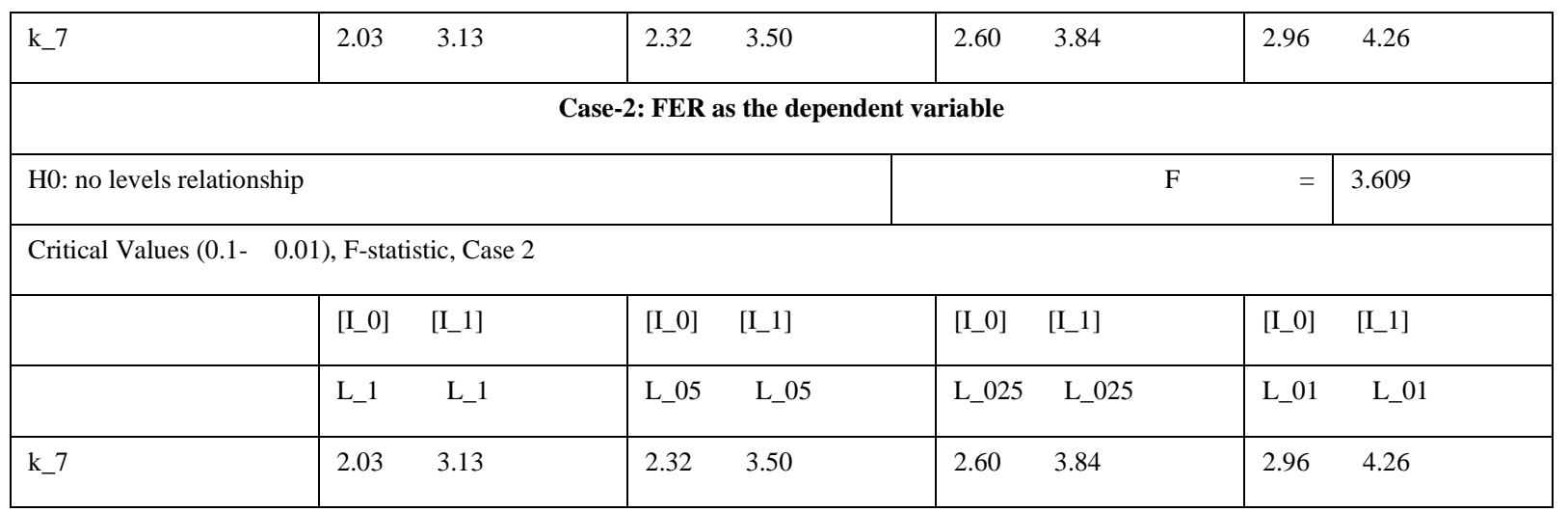

Note: [I_0] and [I_1] are lower I(0) and upper I(1) bound limit, respectively. L_1, L_05, \& L_01 are having the critical values of F-statistic at < 10\%, 5\%, 2.5\% and 1\% significance level, respectively.

Source: By author using Stata 13, 2021

As shown in Table 4 case-2 assuming FER as dependent variable calculated F-statistic is 3.609, which is greater than the upper bound critical values $(=3.50)$ at less than $5 \%$ significance level, thus we reject Ho and conclude that there is co-integration among variables. Therefore, we use ECM to examine the long-run and short-run dynamic relationship between variables and adjustment coefficients that indicates whether there exists convergence towards long-run equilibrium from last year disequilibrium.

\section{$>\quad$ ECM Results for FER}

As shown in Table 4 case 2., due to existence of co-integration among variables when the regressions are normalized on FER, we estimated the ECM as specified below (equation (10)) to show both the long-run and short-run dynamic relationship among variables as well as the speed of adjustment from past year dis-equilibrium (Table 5). The summary statistics for model adequacy were displayed for each equation in the form of coefficient of determination, which is around 55\% indicating that the included variables are predicting variations on FER by around $55 \%$, ceteris paribus.

The ECM result indicates that in the long-run, the variable financial development indicator, DSP, and average trade tariff rate were predicting the stock of FER for Ethiopian economy significantly. The result also indicates that in the short-run variables such as share of agriculture and service sectors were significantly predicting variations of the stock of FER. More importantly, the coefficient of error correction term for FER carries correct sign and statistically significant at less than $1 \%$ significant level with the speed of convergence to equilibrium by approximately $60 \%$.

$$
\begin{aligned}
& \Delta \ln F E R_{t}=a_{01}+\beta_{1 i} \ln \underset{P}{E} P D_{t-i}+\beta_{2 i} \ln F E R_{t_{1}-i}+\beta_{3 i} F D_{t-i}+\beta_{4 i} \ln _{q_{2}} D S P_{t-i}+\beta_{5 i} T_{t-i}+\beta_{7 i} \ln A g r_{t-1}+ \\
& \begin{array}{l}
\beta_{7 i} M a_{t-1}+\beta_{8 i} S v s_{t-i}+\sum_{i=1} a_{1 i} \Delta \ln F E R_{t-i}+\sum_{i=1} a_{2 i} \Delta \ln E P D_{t-1}+\sum_{i=1}^{q_{2}} a_{3 i} \Delta F D_{t-i}+\ldots+\sum_{i=1} a_{8 i} \Delta \ln S v s_{t-i}+
\end{array}
\end{aligned}
$$

ECM result shows that in the long-run financial development impacts level of FER positively and significantly. Accordingly, in the long-run a one unit increment in the financial development indicator raises the stock of FER by around USD 235.5716 which is significant at less than 5\% significance level, keeping other variables constant. This indicates that an improvement in the financial development indicator makes nations more competitive in attracting FDI, thereby improving trade balance and hence this in turn raises stock of FER.

Similarly, the ECM result shows that in the long-run DSP impacts the level of FER negatively and significantly. Accordingly, keeping other variables remain constant, in the long-run a $10 \%$ increment in the amount of debt servicing reduces stock of FER by around $7.07 \%$ which is significant at less than $10 \%$ significance level. This might be due to the fact payments of debts are made in the form of hard currency that deteriorates the stock of FER.

The findings from ECM also indicate that in the long-run trade tariff rate impacts the level of FER negatively and significantly. Accordingly, keeping other factors remain constant in the long-run a $10 \%$ increment of the rate of trade tariff reduces stock of FER by around
$0.36 \%$ which is significant at less than $10 \%$ significance level. This might be in the long-run as countries become less open their accumulation of foreign exchange falls.

According to the ECM the short-run dynamic indicates that both the share of agriculture and service sector negatively and significantly affects stock of FER. In the short-run previous share of agriculture sector from the total GDP significantly impacted on the current level of FER. Keeping other factors remain constant, in the short-run a percentage increase in the past year amount of agricultural share from the economy is capable of reducing current amount of FER by $4.3 \%$ which is significant at less than $5 \%$ significance level. This might be due to the fact that Ethiopia's main source of earning FER is from the export of agricultural products like coffee, Khat, etc.

ECM also indicates that in the short-run previous share of service sector from the total GDP significantly impacted on the current level of FER. Accordingly, in the short-run a percentage increase in the past amount of service share the economy is capable of reducing current amount of FER by $5.5 \%$ which is 
The Dynamics of Foreign Public Debt and Foreign Exchange Reserve of Ethiopia: Autoregressive Distributed Lag Model Approach

significant at less than $5 \%$ significance level, keeping other variables remain constant.

Table 5: Results of Error Correction Model for FER

\begin{tabular}{|c|c|c|c|c|c|c|}
\hline \multicolumn{4}{|c|}{ Sample: 1983 - 2019} & \multicolumn{3}{|c|}{ Number of obs $=37$} \\
\hline \multicolumn{4}{|c|}{ R-squared $=0.5518$} & \multicolumn{3}{|c|}{ Adj R-squared $=0.3546$} \\
\hline \multicolumn{4}{|c|}{ Log likelihood $=25.701552$} & \multicolumn{3}{|c|}{ Root MSE $=0.1470$} \\
\hline D.InFER & Coef. & Std. Err. & $\mathbf{t}$ & $\mathbf{P}>\mathbf{t}$ & [95\% Conf. & Interval] \\
\hline \multicolumn{7}{|l|}{ ADJ } \\
\hline InFER: L1. & -.5991413 & .1615836 & -3.71 & $0.001^{* * *}$ & -.931929 & -.2663535 \\
\hline \multicolumn{7}{|l|}{ Long-Run } \\
\hline $\operatorname{lnEPD}$ & .406852 & .4289128 & 0.95 & 0.352 & -.4765104 & 1.290214 \\
\hline FinancdevtI & 235.5716 & 90.88335 & 2.59 & $0.016^{* *}$ & 48.39385 & 422.7494 \\
\hline InDservcing & -.7071008 & .3538559 & -2.00 & $0.057 *$ & -1.435881 & .021679 \\
\hline TradeTrate & -.0360446 & .0118442 & -3.04 & $0.005^{* * *}$ & -.0604382 & -.0116509 \\
\hline AgrShare & .8630778 & 3.790262 & 0.23 & 0.822 & -6.943114 & 8.669269 \\
\hline ManfcShare & -12.66528 & 8.872936 & -1.43 & 0.166 & -30.93944 & 5.608871 \\
\hline SvsShare & -.7914289 & 4.510018 & -0.18 & 0.862 & -10.07999 & 8.497127 \\
\hline \multicolumn{7}{|l|}{ Short-Run } \\
\hline \multicolumn{7}{|l|}{$\operatorname{lnFER}$} \\
\hline LD. & .274258 & .1727829 & 1.59 & 0.125 & -.0815951 & .630111 \\
\hline \multicolumn{7}{|l|}{ AgrShare } \\
\hline D1. & -4.329497 & 1.993027 & -2.17 & $0.040 * *$ & -8.434213 & -.2247817 \\
\hline \multicolumn{7}{|l|}{ SvsShare } \\
\hline D1. & -5.539179 & 2.542335 & -2.18 & $0.039 * *$ & -10.77521 & -.3031423 \\
\hline _cons & 6.978678 & 3.641652 & 1.92 & 0.067 & -.5214445 & 14.4788 \\
\hline
\end{tabular}

Note: $* * *, * *$ and $*$ indicates less than $1 \%, 5 \%$ and $10 \%$ significance level, respectively.

Source: By author using Stata 13, 2021

\section{Diagnostic Checks Analysis for Error Correction Model}

To check the validity of our models, we conducted different diagnostic checks that include Durbin-Watson test and Breusch-Godfrey test for serial correlation of the error term, Jarque-Bera test for normality, White's test for
Heteroscedasticity and CUSUM graph test for parameter stability. Table 6 indicates that we are accepting the null hypothesis that states there is no auto-correlation, heteroscedasticity, normality problem due to the $\mathrm{p}$-value is greater $5 \%$ significance level.

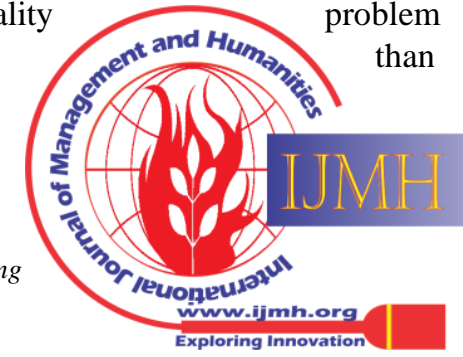


Table 6:Lagrange multiplier (LM) test for serial correlation, and Jarque-Bera test for normality

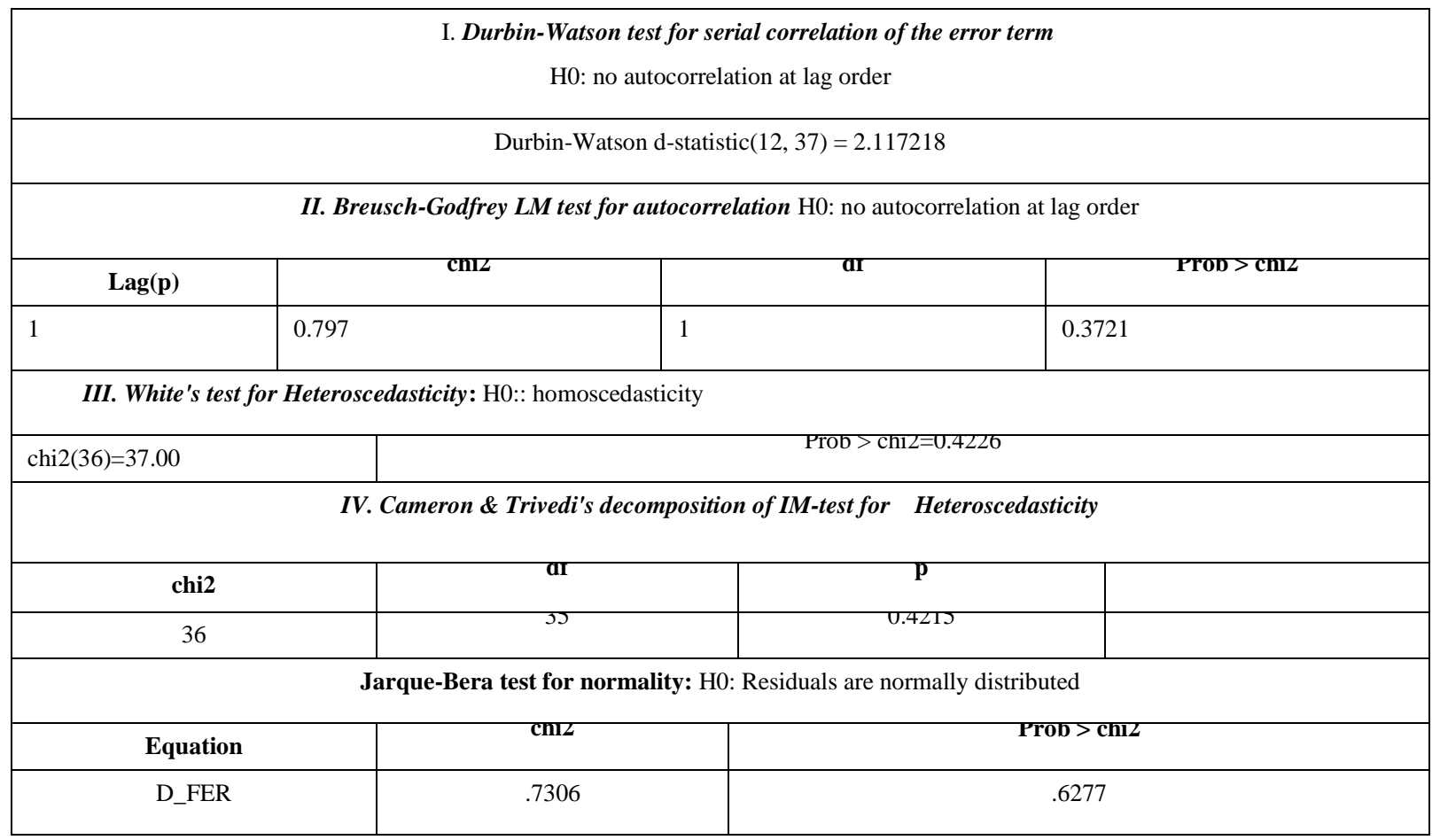

Source: By author using Stata 13, 2021

Since the CUSUM square chart is in between the upper and the lower bounds, indicating that we accept the parameters are stable. Figure 2 displays the stability of specified model as of the graph is within the lower and upper bound limits.

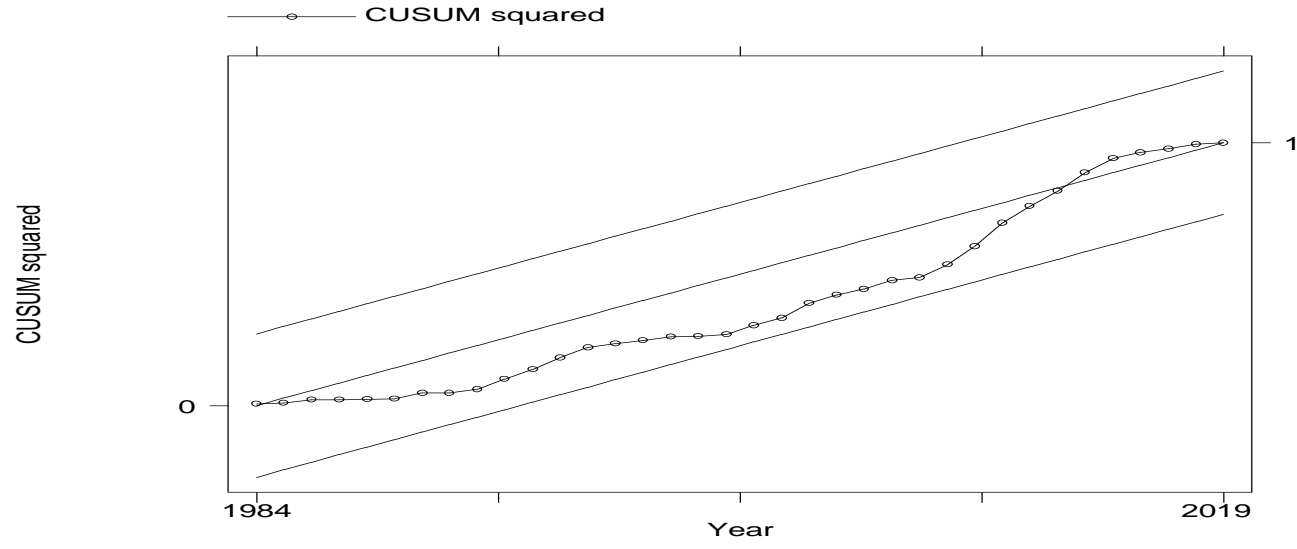

Figure 2: Stability test using CUSUM for FER equation

\section{$>$ Autoregressive Distributed Lag (ARDL) Model Results for EPD}

As to ARDL model result (Table 7) average trade tariff rate, share of manufacturing sector from the GDP and lagged value of EPD itself predict the external public debt significantly at less than $10 \%$ significance level. The short-run result reveal that previous amount of EPD significantly impacted on the current level of EPD. Indeed, in the short-run a $10 \%$ increment in the past three years EPD is capable of reducing current amount of EPD by $10.58 \%$ and which is significant at less than $5 \%$ significance level, keeping other variables constant. This indicates that past period debt alters the current period amount of debt. This might be due to the fact that creditor nations are prioritizing nations with relatively less indebted.

The short-run result reveals that rate of trade tariff rate significantly impacted on the current level of EPD. Indeed, a 10\% increment in previous

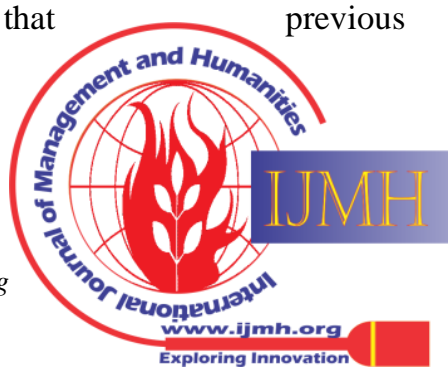




\section{The Dynamics of Foreign Public Debt and Foreign Exchange Reserve of Ethiopia: Autoregressive Distributed Lag Model Approach}

the past year trade tariff rate is capable of reducing current amount of EPD by $0.45 \%$ which is significant at less than $10 \%$ significance level, ceteris paribus. This indicates that as nations builds more open economies their level of indebtedness falls, this might because the nations may develop their economic base and thereby no problem in financing their domestic economy without basing on external sources.

The result from ARDL model also indicates that in the short-run previous share of manufacturing sector from the total GDP significantly impacted on the current level of EPD. Accordingly, in the short-run a percentage increase in past year amount of manufacturing share from the economy is capable of increasing current amount of EPD by $21 \%$ which is significant at less than $5 \%$ significance level, ceteris paribus. This shows that an increase in the current period's share of manufacturing sector tends to increase the coming period EPD. This might be due to the fact that majority of manufacturing industries are financed by long-run EDs, and even the extent is higher in the last five years, due to the expansion of industrial parks in Ethiopia.

Table 7: ARDL Model for EPD equation

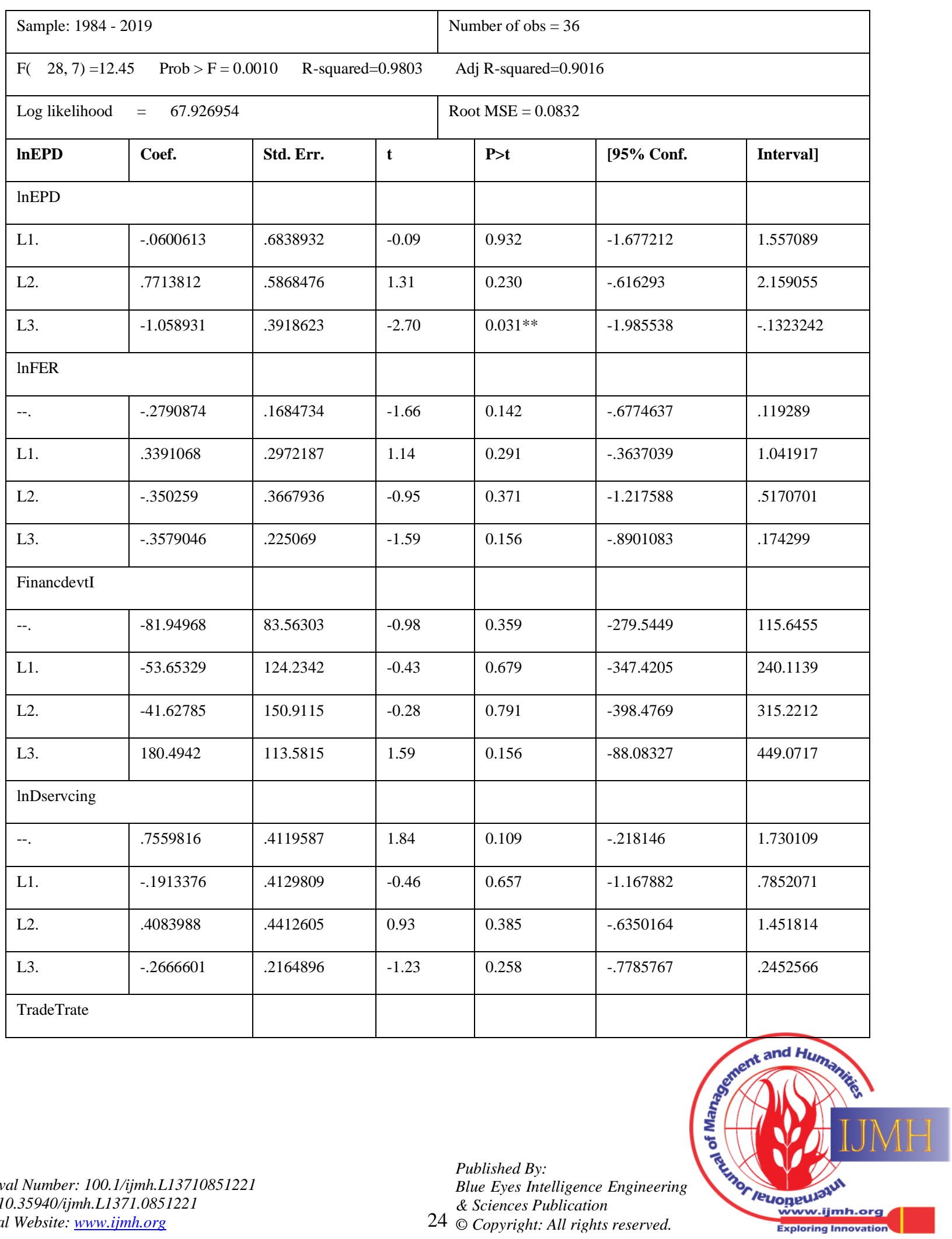




\begin{tabular}{|c|c|c|c|c|c|c|}
\hline.-- & .0227297 & .0291363 & 0.78 & 0.461 & -.0461666 & .0916261 \\
\hline L1. & -.0446141 & .0204864 & -2.18 & $0.066^{*}$ & -.0930568 & .0038286 \\
\hline \multicolumn{7}{|c|}{ AgrShare } \\
\hline.-- & .978917 & 2.107962 & 0.46 & 0.656 & -4.00562 & 5.963454 \\
\hline L1. & -.0027747 & 2.651554 & -0.00 & 0.999 & -6.272704 & 6.267155 \\
\hline L2. & -4.187868 & 2.758936 & -1.52 & 0.173 & -10.71171 & 2.335978 \\
\hline \multicolumn{7}{|c|}{ ManfcShare } \\
\hline --. & -9.44911 & 9.64467 & -0.98 & 0.360 & -32.25513 & 13.35691 \\
\hline L1. & 21.02009 & 7.685078 & 2.74 & $0.029^{* *}$ & 2.847772 & 39.19242 \\
\hline L2. & -6.518668 & 9.950619 & -0.66 & 0.533 & -30.04814 & 17.01081 \\
\hline L3. & -14.91981 & 8.978064 & -1.66 & 0.141 & -36.14956 & 6.309935 \\
\hline \multicolumn{7}{|c|}{ SvsShare } \\
\hline --. & .0141722 & 2.628431 & 0.01 & 0.996 & -6.20108 & 6.229425 \\
\hline L1. & 1547106 & 3.002948 & 0.05 & 0.960 & -6.946133 & 7.255555 \\
\hline L2. & -3.974569 & 3.301772 & -1.20 & 0.268 & -11.78202 & 3.832881 \\
\hline L3. & -2.236086 & 1.271649 & -1.76 & 0.122 & -5.243059 & .7708868 \\
\hline _cons & 17.01702 & 7.127027 & 2.39 & 0.048 & .1642792 & 33.86976 \\
\hline
\end{tabular}

Note: $* * *, * *$ and $*$ indicates less than $1 \%, 5 \%$ and $10 \%$ significance level, respectively.

Source: By author using Stata 13, 2021

\section{> Diagnostic Checks Analysis for ARDL Model}

To check validity of our models, we conducted different diagnostic checks that include Durbin-Watson test and Breusch-Godfrey test for serial correlation of the error term, Jarque-Bera test for normality, White's test for Heteroscedasticity and CUSUM graph test for checking parameter stability. The result in Table 8 indicates that we are accepting the null hypothesis that states there is no auto-correlation, heteroscedasticity, normality problem due to the p-value is greater than $5 \%$ significance level.

Table 8: Lagrange multiplier test for serial correlation and Jarque-Bera test for normality

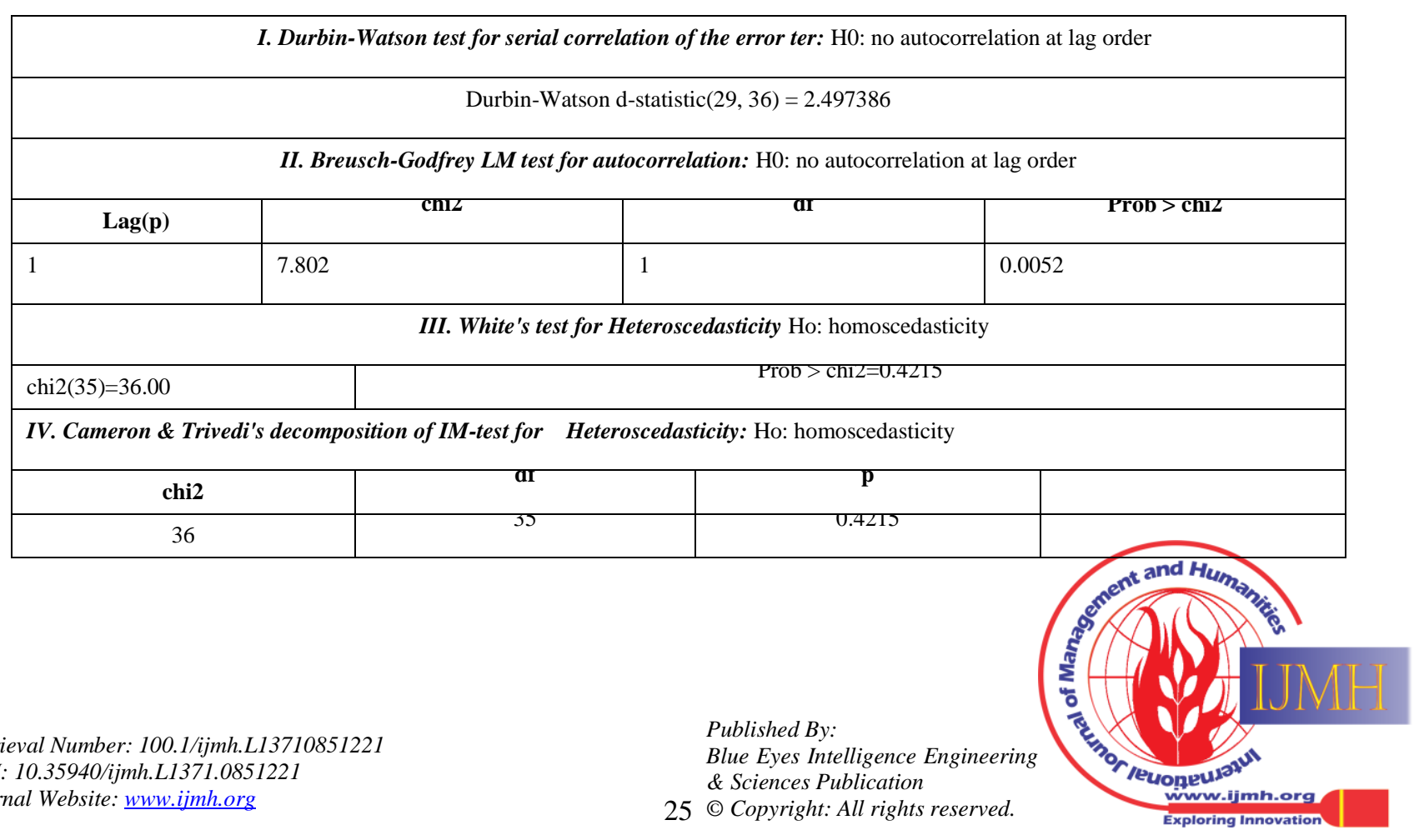


The Dynamics of Foreign Public Debt and Foreign Exchange Reserve of Ethiopia: Autoregressive Distributed Lag Model Approach

\begin{tabular}{|l|l|l|l|}
\hline \multicolumn{4}{|c|}{ V. Jarque-Bera test for normality: H0: Residuals are normally distributed } \\
\hline Equation & CIII & II & ProD > CnIL \\
\hline D_EPD & .2992 & & 2.414 \\
\hline
\end{tabular}

Source: By author using Stata 13, 2021

Since the CUSUM square chart is in between the upper and lower bounds indicating that we accept the parameters are stable. Figure 3 displays the stability of our specified

model as of the graph is within the lower and upper bound limits.

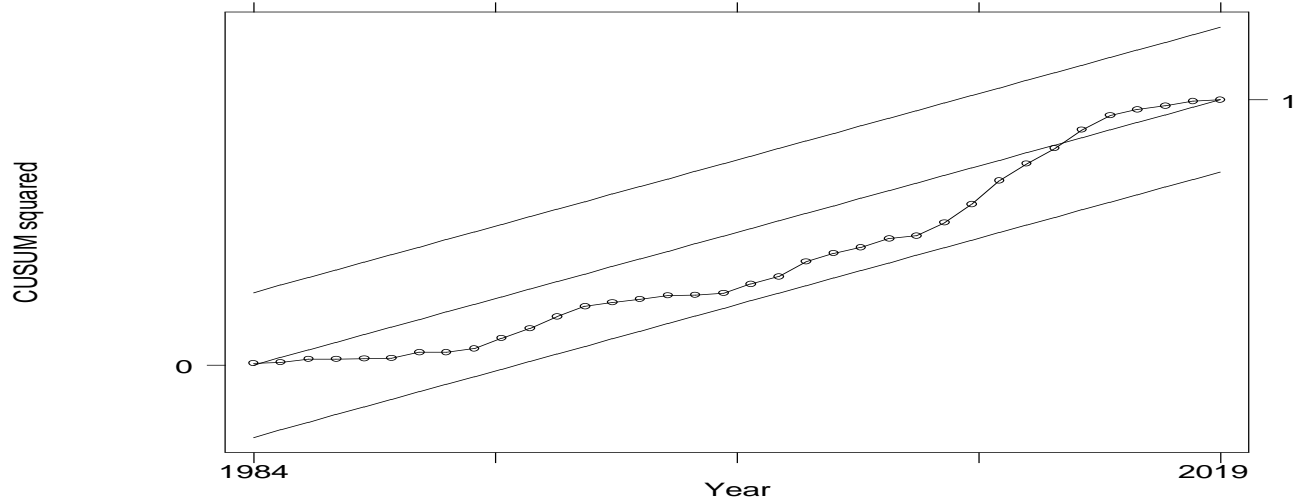

Figure 3: Stability test using CUSUM for EPD equation. Source: By author Stata 13, 2021

\section{CONCLUSION AND IMPLICATIONS}

Ethiopia is struggling with a huge shortage of FER for the last two decades. Data for the year 2018 indicated that FER was only adequate to cover 1.6 month of imports or valued approximately USD 2.8 billion. Consequently, many of the businesses waited on average six months to get foreign currency to import capital goods and services. The dual gap theory of ED and self-insurance theory of reserves showed the economy is mainly inclined on external financing issues which in turn had its own consequences on foreign reserves in the long run. This study limited its scope to 1981 to 2019 for 39 years due to the availability of data-sets for these periods. The study only considers the long-term EPD due to the permanent component nature of EPD types and FER as target variable and other macroeconomic variables like financial development indicator, share of economic sectors of the GDP, etc. as control variables.

To achieve the objective both descriptive and empirical methods of analysis were used. Different post-estimation tests and diagnostic tests were conducted to examine economic series of variables. To examine their relationships ARDL model was adopted with the extension of ECM. Accordingly the study had found the following key findings.

$\checkmark \quad$ The EPD of Ethiopia is increasing dramatically indicating huge public investments in Ethiopia like industrial parks which are financed by EPD. The FER level shows an improvement after the downfall of Dergue in 1991 and yet limited with the maximum amount below USD 4 billion. These show that the coming generation will incur costs with holding of high ED and dangerously low level of reserves by the country.

$\checkmark \quad$ On average, in Ethiopia the trend for service sector indicated that an ever improvement of the sector

throughout the periods and supplementing the notion of change from agriculture base to service sector. This is inconsistent with the government plan of GTP I and II, which might be due to the fact that in the last decades the expansion of service sector like hotel, tourism, lodge and etc. have taken the lions share.

$\checkmark \quad$ As to ARDL model in the short -run average trade tariff rate, share of manufacturing sector from the GDP and lagged value of EPD itself predicts the EPD significantly at less than $10 \%$ significance level.

$\checkmark$ The ECM for FER indicates that in the long-run, financial development indicator, DSP and average trade tariff rate were predicting the stock of FER for Ethiopian economy.

$\checkmark \quad$ The ECM result also indicates that in the short-run, only the share of agriculture and service sectors were significantly predicting the variations of the stock of FER.

According to the findings of this study the following major recommendations are forwarded:

- The government, NBE and other concerned bodies should take necessary steps to enhance the FER base of the country by focusing on improving the export standards of value added primary products.

- Since DSP affects negatively the level of FER in the long-run, the government of Ethiopia should limit or reduce the amount of ED inflows that has an adverse effect on debt service payment.

○ The government should recheck budget sources for financing different projects especially manufacturing industries rather than highly basing on external sources in the form of EPD.

- Other researchers in the can conduct in related topic by increasing the time frame and

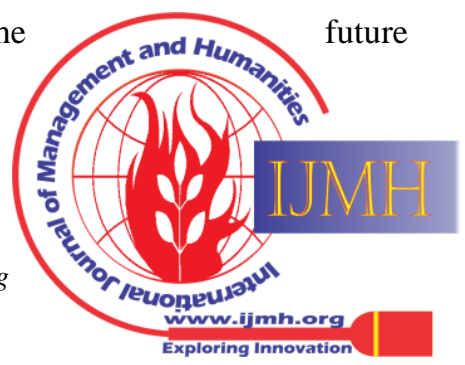


including other macroeconomic factors that affect FER of the nation.

\section{CONFLICT OF INTEREST}

Authors of this article declare none.

\section{ACKNOWLEDGEMENTS}

We would like to gratefully acknowledge World Bank and National Bank of Ethiopia for provision of data. In addition, special thanks to Wolaita Sodo University and Arba Minch University, Ethiopia for their support. Last but not least, many more thanks to these who provided valuable comments and suggestion on the construction of the paper. The findings and conclusions in this publication are those of the authors and should not be construed to represent any organization.

\section{REFERENCES}

1. Alfaro L. and Kanczuk F. (2005): "Sovereign debt as a contingent claim: a quantitative approach" Journal of International Economics, Vol. 65, (2). 297-314

2. Bangura S. (2004): "External Debt Management in Low Income Countries." IMF working paper, No. 00/196

3. Borensztein E. (1990): "Debt Overhang, Debt Reduction and Investment: The case of the Philippines." IMF Working paper, No. $\mathrm{WP} / 90 / 77$.

4. Clements B., Bhattacharya R. and Quoc T. (2003): "External Debt, Public Investment, and Growth in Low-Income Countries", IMF Working Paper Working Paper, No. WP03/249.

5. Engle R. and Granger C. (1987): "Co-integration and error correction: Representation, estimation and testing." Econometrica,. Vol 55, 251-276.

6. Fukuda S. and Kon Y.(2010): "Macroeconomic Impacts of Foreign Exchange Reserve Accumulation: Theory and International Evidence.” ADBI Working Paper 197. Tokyo: Asian Development Bank Institute. Available: http://www.adbi.org/workingpaper/2010/02/19/3515.macroeconomi c.impact.forex.reserve.accumulation/

7. Gergely Baksay, Ferenc Karvalits and Zsolt Kuti. (NA): “The impact of public debt on foreign exchange reserves and central bank profitability: the case of Hungary." BIS Papers No 67.

8. Green W. (1989): "Econometric Analysis". Pearson Education, Inc, New Delhi.

9. Gujarati D. (2003): "Basic Econometrics." 4th edition: McGraw Hill co., New York,

10. Hiro Ito and Robert N.McCauley (2010): Currency Composition of Foreign Exchange Reserves. Journal of International Money and Finance. Volume 102.

11. International Relations Committee Task Force (2006): "The Accumulation of Foreign Reserves" ECB Occasional Paper, No. 43 , European Central Bank (ECB), Frankfurt a. M.

12. Iyoha M. (1999): "External Debt and Economic Growth in Sub-Saharan African Countries: An econometric study." African Economic research Consortium research paper No. 90, English Press LD.

13. Johansen S. (1991): "Estimation and Hypothesis Testing of Co-integration Vectors in Gaussian Vector Autoregressive Models." Econometrica, Vol. 59, 1551-1580.

14. Johansen S. (1995): "Likelihood-based Inference in Co-integrated Vector Autoregressive Models." Oxford: Oxford University Press.

15. Krugman P. (1988): "Financing versus Forgiving a Debt Overhang. Journal of Development Economics.” 29,5

16. Kurmas Akdoğan (2012): "Foreign Exchange Reserves In a Credit Constrained Economy." Journal of International Economics. 130, 59-79.

17. Layal Mansour (2013): "International Reserves versus External Debts: Can International reserves avoid future Financial Crisis in indebted Countries?" halshs-00864899.
18. Mankiw, G., Romer, D. and Weil, D. (1992): “A Contribution To The Empirics Of Economic Growth.” Quarterly Journal of Economics. 107, 407-437.

19. Mei-yin L. (2011): "Foreign Reserves and Economic Growth: Granger Causality Analysis with Panel Data", Economics Bulletin, 31 (2) 1563-1575.

20. NBE, (2019): “Annual Report” Prepared by Economic Research and Monetary Policy Directorate, NBE various issues,

21. Pattillo C., Poirson H. and Ricci L. (2011): "External Debt and Growth." Review of Economics and Institutions, 2, 1-30.

22. Pesaran M. and Shin Y. (1999): "An Autoregressive Distributed Lag Modelling Approach to Co-integration Analysis.” In S. Strom (Ed.), Econometrics and Economic Theory in the 20th Century: The Ragnar Frisch Centennial Symposium, Cambridge University Press, 371-413.

23. Pesaran M., Shin Y. and Smith R. (2001): "Bounds Testing Approaches to the Analysis of Level Relationships." Journal of Applied Econometrics, 16, 289-326.

24. Peter E. and Dumani M. (2020):“"Impact of External Debt on Nigeria's Foreign Reserve Portfolios." Asian Journal of Economics and Empirical Research, 7(1), 1-7.

25. Ramakrishna G. 2002: "External Debt of Ethiopia: An Empirical Analysis of Debt and Growth.” Journal of Business and Public Affairs .

26. Taylor L. (1994): "The Rocky Road to Reform, Trade, Industry and Agriculture." World bank publication.

27. Victoria Senibi,Emmanuel Oduntan, Obinna Uzoma, Esther Senibi and Akinde Oluwaseun. (2016): "Public Debt and External Reserve: The Nigerian Experience (1981-2013).” Hindawi Publishing Corporation, Economics Research International, Volume 2016, Article ID 1957017.

\section{AUTHORS PROFILE}

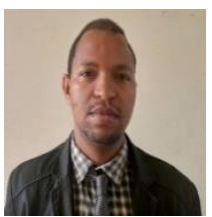

Solomon Kebede Menza, (PhD Candidate at Arba Minch University) Lecturer \& Researcher, Department of Economics, Wolaita Sodo University Email: kebedes24@gmail.com

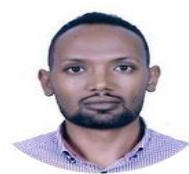

Zerihun Getachew, (PhD) Senior Researcher ,World Bank branch in Addis Ababa, Ethiopia. Email: zgetachewkelbore@worldbank.org

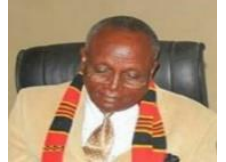

Tora Abebe, $(\mathrm{PhD})$ Senior Lecturer and Researcher, Arba Minch University, Ethiopia. Email: Toraabebeduka@yahoo.com

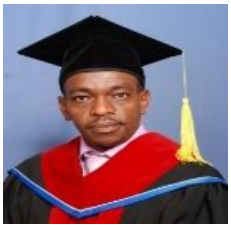

Berhanu Kuma, (PhD, Associate Professor) Senio Lecturer and Researcher, Wolaita Sodo University, Ethiopia.bEmail: berhanukuma@yahoo.com
Published By:

Blue Eyes Intelligence Engineering \& Sciences Publication

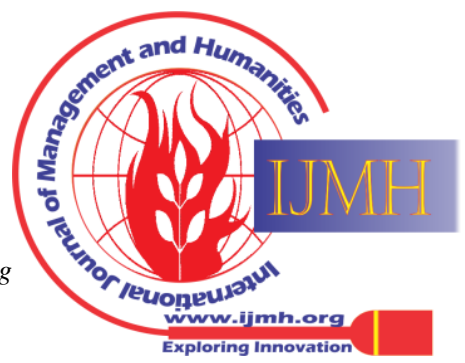

